\title{
Ugwuele Prehistoric Site in Nigeria: Controversies and Directions
}

\author{
Elochukwu A Nwankwo ${ }^{1 *}$, Edmund I Itanyi ${ }^{2}$ \\ Department of Archaeology and Tourism, University of Nigeria, Nigeria
}

Submission: January 01, 2021; Published: January 29, 2021

*Corresponding author: Elochukwu A Nwankwo, Department of Archaeology and Tourism, University of Nigeria, Nigeria

\begin{abstract}
s
Acheulean culture has been identified as one of the oldest industrial sites (for archaeological studies) with large quantities of Acheulean cultural tools like handaxes, cleavers, picks, side scrapers etc. A cross-cultural dating had earlier revealed that a similar culture may have existed in Ugwuelle, Southeastern Nigeria. The archaeological research was conducted by F.N. Anozie and his team in 1977. This has further raised some critical thoughts on the true position of this Ugwuelle site as having existed as an Acheulean site. For instance, there are currently divided opinions amongst scholars as to whether Ugwuelle artifacts are truly Acheulean or pre-forms of Achulean bifaces. Some authors like Philip Allsworth-Jones see the site as an axe factory with possible Holocene date. This paper advocates a systematic and detailed revisit of archaeological finds of this particular site in Nigeria to sought ways of aligning it with other known Acheulean sites in the world. This study was carried out using archaeological reconnaissance and a review of related literatures to make its positions. The implication of this paper is to further make clarifications on the true position of the Ugwuelle archaeological site in Nigeria.
\end{abstract}

Keywords: Acheulean; Stone tools; Ugwuele; Sites; Archaeology; Reconnaissance; Excavation

\section{Introduction}

Archaeological discoveries overtime have aided in tracing the origin and generational root of man from inception [1]. This is one of the reasons why the discipline of archaeology had commanded much respect and regard from some other disciplines. The archaeological study of earliest human settlement in the world is made possible through the understanding of various archaeological remains especially that from different regions of Africa. The archaeological record has been identified as a cultural period when the Homos (habilis and erectus) lived and made useful implements for a sustainable living. Braq \& Trump [2] noted that; In Europe the term Acheulian is used for the later (i.e. post -ABBEVILLIAN) stages of the lower PALAEOLITHIC HANDAXE tradition. The conventional borderline between Abbevillian and Acheulian is marked by a technological innovation in the working of stone implements, the use of a flaking tool of soft material (wood, bone, antler) in place of a hammer stone... the type site is in France at Saint Acheul, Amiens, where the implements were found in deposits of the early part of the RISS glaciations. Study of evidences and other archaeological excavations are still revealing the spread of archaeological remains to some other continents of the world as Acheulean and other similar cultures of Abbrevillian, Chellean, etc which were said to have existed during the lower Paleolithic have been noticed to have existed in Africa and Europe.
For instance the Chellean term was said to have been used to represent archaeological cultures during the lower Palaeolithic Hand axe tradition in Europe. Also the Chellean was said to have evolved to what is referred to today as the Acheulean hence the term Chelleo-Acheulean was formerly used for the succession of hand axe industries in Africa but has been replaced today by what is popularly known as Acheulean culture [2]. This later degenerated from the Acheulean to some other cultures, as man was rapidly developing both in thoughts and innovations through the exploration of various resources in the environment. There was equally increase in human population and tool traditions [3-5]. However, observations, excavations, inferences and other lab analysis are still in progress towards perfecting the true knowledge of existence of the early man in some parts of the world through cultural resemblances and linkages of notable archaeological cultures. As noted earlier, the understanding of activities of the early man in place is a function of availability and analysis of tools made and used like wood, stone, clay, metal, fossil remains and other available evidences.

Previous archaeological research in Africa had revealed that man originated from Africa throughout the whole world and his traces from the early Australopithecines to the Homo species. Evidence on this occur not only on the remains of man himself, 
but also on the tools he produced and used. These early human developments in Africa occurred in stages and were marked by different cultures. Thus, we have the Oldowan culture noted with tools like the choppers, spheroids and polyhedrals. Then the Achulean culture marked with tools like handaxes, cleavers, side scrapers and flakes. In some cases, picks are found in the assemblage. There is also the Sangoan culture marked by the picks. This claim on the origin from and spread out of Africa moved Alagoa \& Derefaka [6] to write "Man began to move out of Africa, the first evidence of appearance of Homo sapiens about 200,000 years ago occurred again in Africa. Africa can, therefore, be said to be not only the cradle of mankind, but also the re- engineering homeland for humans". The Acheulean culture marked by the above-mentioned tools which are the hall mark of this work has been found in many parts of Africa. Generally, it is associated with the genus Homo erectus (the erect moving hominid). Amongst the areas/sites where the Acheulean had been found in Africa are; West Africa - in Mali, Mauritania, Senegal and Nigeria. Within Nigeria, we have Jos Plateau in the sites of Mai Idon Toro, Pingell, Iying and the Nok valley. Allsworth-Jones [7] refers to Jos plateau area as the best for Acheulean in tropical West Africa. Ugwuele is another likely destination of Acheulean as was informed by Anozie [8]. Anozie [9] described his perception on the discovery of the site in 1977, in the following lines "We are not aware of any other site in the world with such an enormous amount of stone axes and other tools. An explanation is possible. Since suitable stone flaking materials were not available in the area, it is understandable if the
Acheulean camped at the site for a very long time in order to use the dolerite in the manufacture of tools which were very essential to them. It is also likely that tools made at Ugwuele were used at places far away from the site".

\section{The Ugwuele Archaeological Site (1977).}

The Nigerian site of Ugwuele-Uturu has attracted widespread interest since its discovery in part because of F. N. Anozie's original description of it as Acheulean [10]. This site is about 7kms North of Hope - Ville Rehabilitation centre which is found immediately one enters Uturu Okigwe which is about $10 \mathrm{kms}$ east of Okigwe on the Okigwe Afikpo road [11]. It has $5053^{\prime} \mathrm{N}, 7026^{\prime} \mathrm{E}$ as its coordinates (Figure 1). While the vegetation of the site is savanna, “...dominant grasses are Pennisteum purpuram and Andapogon sp., with a sprinkling of others such as Imperata cylindrical. The few trees present include oil palm and Phyllanthus descoideus" [12]. Also, the vegetation of the area is also made up of shrubs and stunted trees like Acioa batari and Velvet tamarind (Figures 2 \& 3). Allsworth-Jones [10] is of the opinion that the event that really exposed the site to the attraction of academic interests and subsequent researches was the activities of the quarrying company in the area. It has been described as the largest Stone Age factory in the world. Materials found here occur in stratigraphically sealed context and made from dolerite, an intrusive, fine-grained igneous rock $[11,14]$. The site was originally discovered in October 1977 and first investigated by a team of archaeologists from the University of Nigeria Nsukka [10].

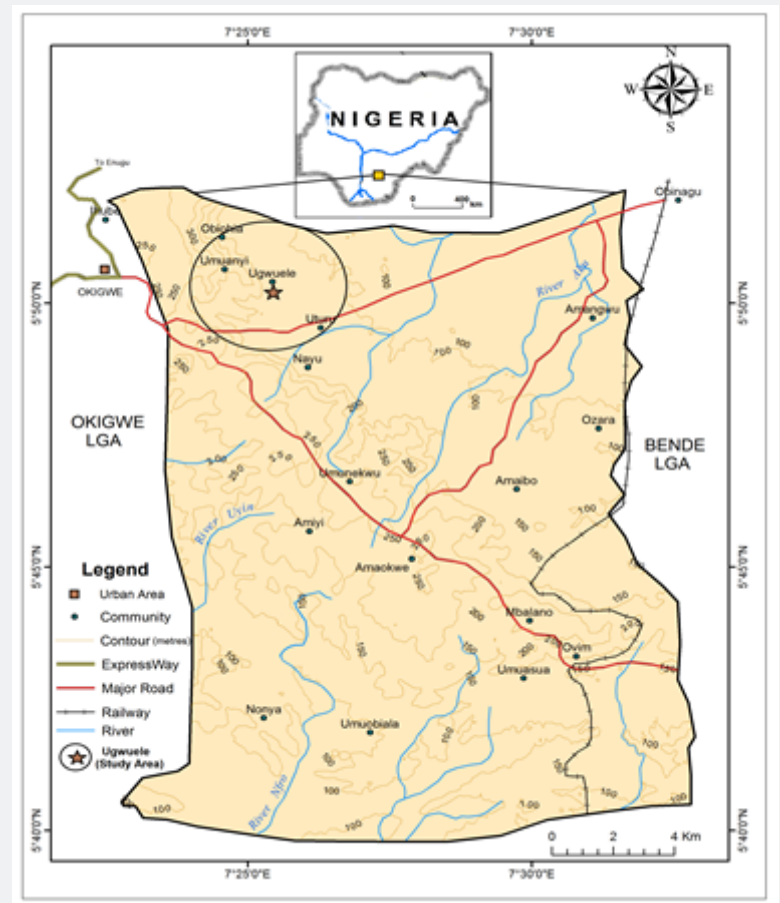

Figure 1: Map of Isuikwuato Local Government Area of Abia State, Ugwuele in circle.

(Source: Fieldwork, 2014) 


\section{Global Journal of Archaeology \& Anthropology}

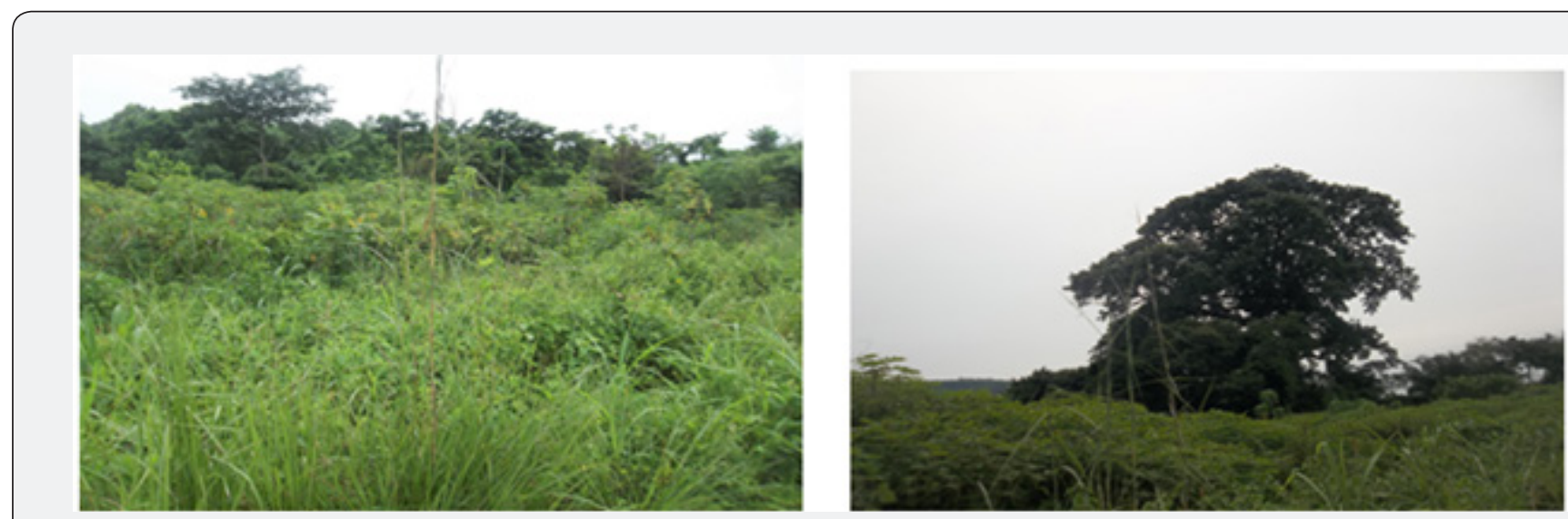

Figures 2 \& 3: The Vegetation of Ugwuele Stone Industrial Site.

The inconclusive nature of the Ugwuele archaeological investigation raised conflicting opinions amongst the actors who worked on the site. For instance, Allsworth-Jones has vehemently disagreed with Anozie who the Principal Investigator on the true nature of the lithic materials was discovered from the Test Pits conducted in the site. For instance, Allsworth-Jones was of the opinion that 'the artifacts presented (by Anozie) ... as a 'Point', but the lower surface is worked and it appears to have been abandoned before completion. Of course, if the process described above is regarded as no more than roughouts, then the rather fancy morphological names given to them are illusory" [10]. Also, in his (Allsworth-Jones) current publication, he informed that Anozie could not date his samples hence he inquired from the dating company who denied any record of such sample from Anozie as was claimed. But Anozie [8] never claimed to have dated the samples as was claimed. He maintained that he wanted to date those samples but had a challenge which made the process inconclusive. This all-important archaeological site has been denied of extensive and detailed excavation to ascertain the true nature of the site and as well silence the long-existed arguments that have emanated from the site since its first preliminary investigation in 1977. Hence while Anozie was projecting the site as an Acheulean site, Allsworth-Jones insisted that the site could have been an axe factory site and that the only Acheulean site to have existed in Nigeria is within the vicinity of Jos Plateau where him (Allsworth-Jones) and Anozie were part of the archaeological investigators in the site. Also, Allsworth-Jones agreed with Marliac [14] who maintained that sites can equally be found at various localities within the vicinity apart from their original sources. To this regard Allsworth-Jones [10] expressed that "one could expect that the same might be true for Ugwuele-Uturu". J. D. Clark had a different view of the site from that of Anozie when the result of the preliminary investigation was presented by Anozie, Andah and Derefaka during the 9th Pan-African Congress in Jos in December, 1983. This he made known in his report in 'Nyame Akuma' 1983 [10]. Clark views the site just like Allsworth-Jones, as an axe factory site that are found in some parts of Africa like Cameroon. He declined from giving a clear nod to the postulation that the site is an Acheulean. Infact both Clark [14] and Allsworth-Jones [10] in their publications reported that the conference paper presented on the Ugwuelle studies during the 1983 Pan-African Congress at Jos by Anozie and other prominent actors in the investigation, was not published as a full paper in the conference proceedings except the short abstract. But they (Clark and Allsworth-Jones) failed to inform the cause of this accidental exclusion of the paper from the preceding conference proceedings. The question now is, was it excluded for lack of merit? Baseless argument. Author's decision? Regional and/or continental bias?, Or academic sentiments and politics? This has opened up the need for the arguments and demands of this paper. Much have been said on the archaeological evidence at Ugwuele in Uturu area of Abia State, Nigeria, with respect to the evidence of existence of early industrial sites in the area owing to the discovery of early stone tools in large quantity at a particular area of the community that are not habited by the extant society but used occasionally as farm site by the community. Anozie F. N. led the first archaeological investigation of the site and concluded that the site was Acheulean. This view did not go well with that of Allsworth-Jones who profusely criticized this view from Anozie and maintained that the site could have been an ax factory site with a possible Holocene date $[8,10 \& 11]$. In this site, many stone tools similar to that of the Acheulian culture have been identified i.e. handaxes, cleavers and Picks revealing the possibility of the existence of a culture similar to the other Acheulean cultures known in the world Anozie, Chikwendu \& Umeji [11]. The true nature of the site is still a vague as extensive investigation is still a mirage. "The only published but still avowedly preliminary description of the site has been given by the Late F. N Anozie who directed the UNN excavation at Ugwuele over an eight-week period during November 1977 to March 1978" [10]. However, the nature and location of these stone tools coupled with issues on human use and natural factors have formed major questions for cultural thoughts on the site and its 
position in archeological evidence and analysts of the early human settlement in Africa. These amongst other issues this paper tends to address.

In this study, ground reconnaissance enabled for the corpus collection of lithic samples from the site. This is coupled with detailed field observation and critical content analysis of previous contending literatures on the subject matter. During the ground reconnaissance, most of the broken lithic artifacts were randomly collected and sorted typographically. Furthermore, the entire site area and environs were walked round and many cultural and natural features like shrines, groves, caves and rock shelters which give clue to early human settlement in the area were observed. Site Catchment Analysis (SCA) of Ugwuelle site was conducted 5-6 kilometres radius or one hour work, to study the various landscapes as earlier mentioned. Among these were Ugwuogwu iron smelting site, Nnemchukwu cave, Okpuchukwu cave, Ogu-agor cave and rock shelter, the grove of Nwogba stream made up of a vegetation cover that consist of majorly of mat plants (pandamus pandam) which are also features possible early human settlement in the study area. Descriptive and evaluative methods of data analysis were employed for data analysis.

\section{The Genesis of the Site Discovery}

It all began in 1977 when a student in the Department of Geography, University of Nigeria, Nsukka, visited a quarry site in his home town of Ugwuele in the present Isuikwuato Local Government of Abia State, Nigeria. He saw many stone flakes in large quantity scattered over a large area of land (Figures 4 \& 5). He thought of the academic relevance of the discovery, and decided to report it to Professor G.E.K Ofomata of the Department of Geography, University of Nigeria, Nsukka. Professor Ofomata immediately understood the archaeological implications of those stone flakes and took a wise decision of taking some of them to the Archaeological Laboratory of the University of Nigeria, Nsukka for professional analysis and interpretation. The site was later visited by professional archaeologists from the Department of History and Archaeology, University of Nigeria, Nsukka, in October, 1977 for a rescue excavation. It was recorded that during this excavation, two test pits of $2 \mathrm{~m}$ by $2 \mathrm{~m}$ each coupled with two trenches of $6 \mathrm{~m}$ by $2 \mathrm{~m}$ each were excavated. Apart from the Initial archaeological investigation of the site in 1977 led by F. N. Anozie of the blessed memory, another archaeological investigation was carried out in 1981 by a team from the University of Nigeria Nsukka, University of Ibadan and the Nigerian National Museum which is currently referred to as the National Commission for Museums and Monuments (NCMM) [8-10, 16-18]. At the end so many stone tools which included handaxes, cleavers, stone knives, picks, were discovered in industrial quantity. The discovered stone tools were made of dolerite [19]. Details of findings from these series of minor archaeological investigations of the site can be found in the publications of prominent actors in that exploration (i.e. Anozie et al. 1978; Anozie 1982; 1983; 1985; 1993; Andah \& Derefaka 1983; Allsworth-Jones 1987; 2015; etc). It is not the intension of this paper to revisit the details of finds from those archaeological investigations on the site which have already been stated in many previous studies like the ones mentioned above, but this paper is more interested in the controversies that were generated as a result of these finds and the escape route towards establishing the true nature of the site devoid of any form of sentiments and prejudices.

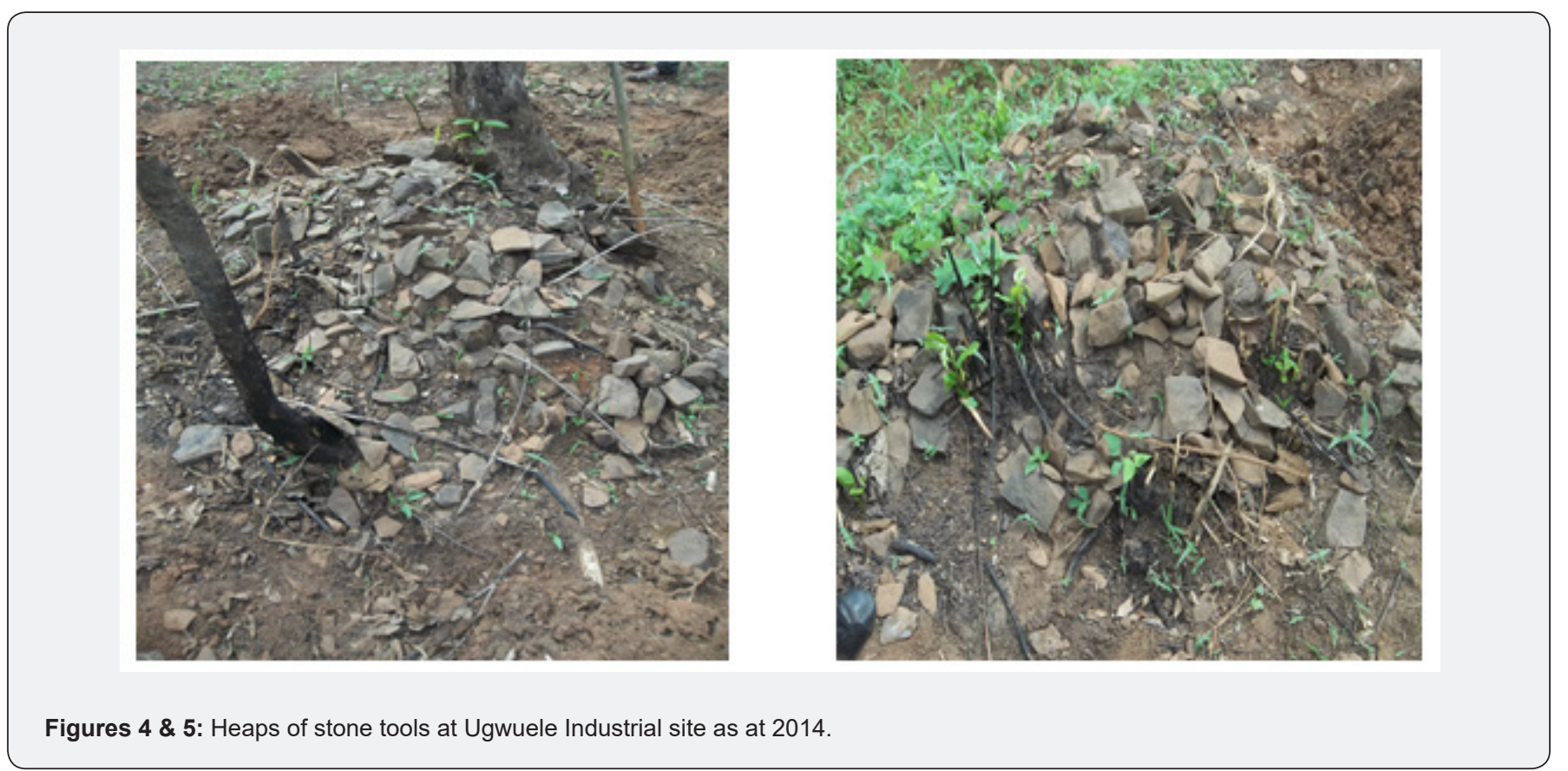




\section{Global Journal of Archaeology \& Anthropology}

As at the time of the most recent ground reconnaissance on the site, (between 19th - 23rd May 2014), the quarrying company was still going on with its quarrying activities in the site. Though they reserved some part of the site for future archaeological studies as they promised when the site was discovered in 1977 , the site is faced with serious threat of destruction as tones of the materials were being quarried on daily basis and carried away for road construction and other uses. Anozie [9] informed that the site is not dated yet but can be undisputedly put at between 1.6 million and 95,000 years BP. He concluded that from the studies of Clark [20], the Ugwuele site (Figures 6-13) could belong to the later phase of Acheulean which has been dated to about 500,000 years BP. Anozie [9] went ahead to assert that "We are trying to obtain a more definite date using Carbon-14 and Potassium argon techniques of dating as suitable dating materials were found at the site during the excavation, although we have some problems with these two techniques. We have also invited a geologist and a palynologist to see if the site could be dated by other means". This was in contrast to the accusations from Allsworth-Jones who reported that Anozie claimed to have taken the samples to a lab for dating.

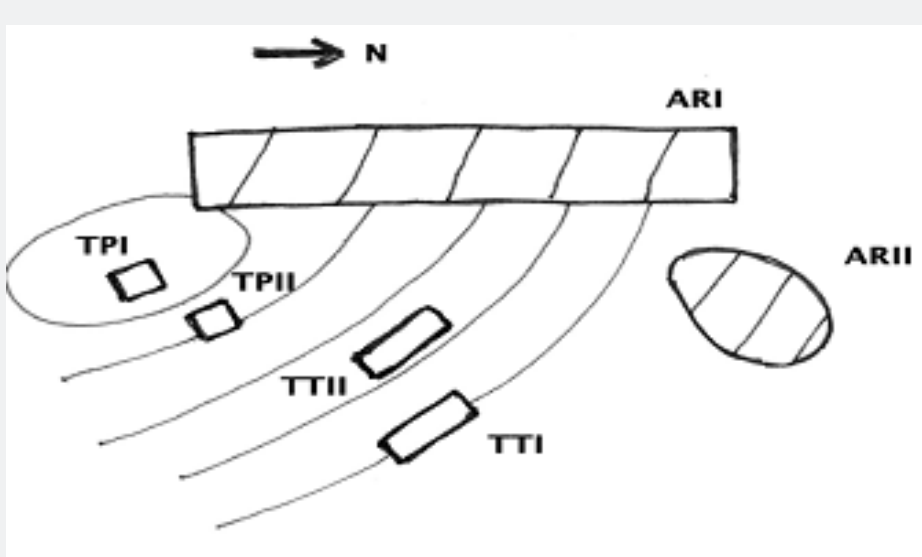

TP Test Pit TT Test Trench AR Archaeological Reserve

Figure 6: Sketch plan of the site (after Anozie 1982).

(Source: Allsworth-Jones, 2015)

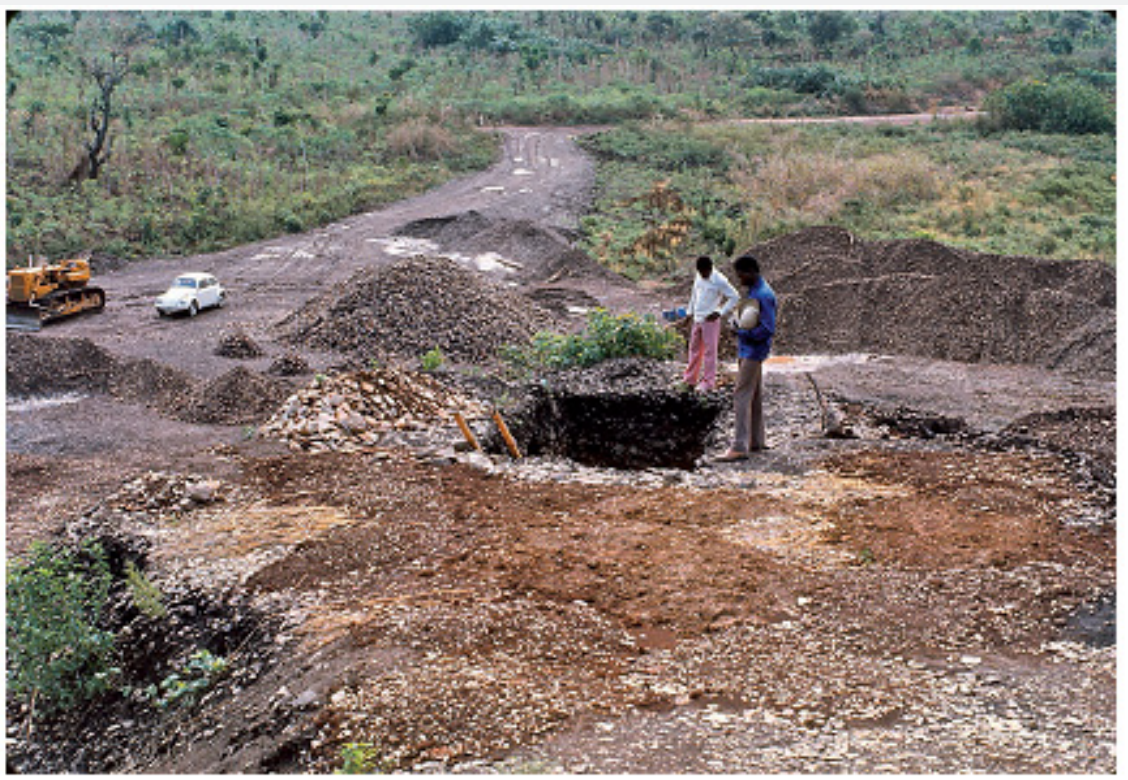

Figure 7: Position of Test Trench I (UNN 1977-1978).

(Source: Allsworth-Jones, 2015) 


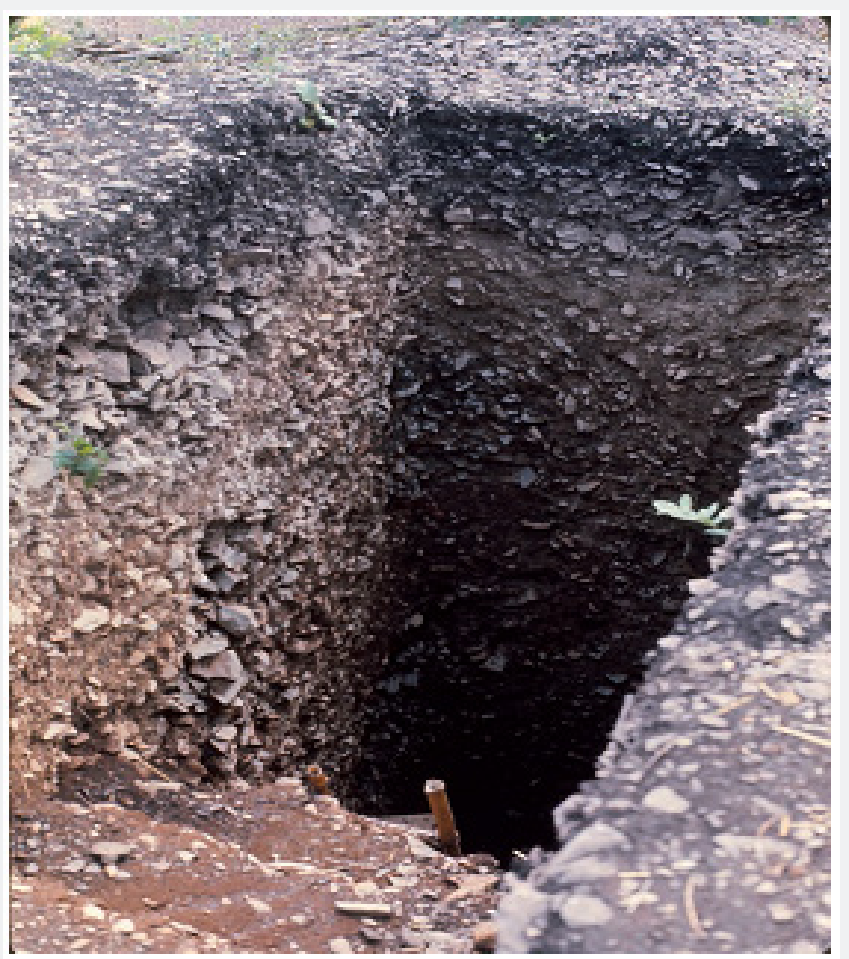

Figure 8: Test Trench I (UNN 1977-1978).

(Source: Allsworth-Jones, 2015)

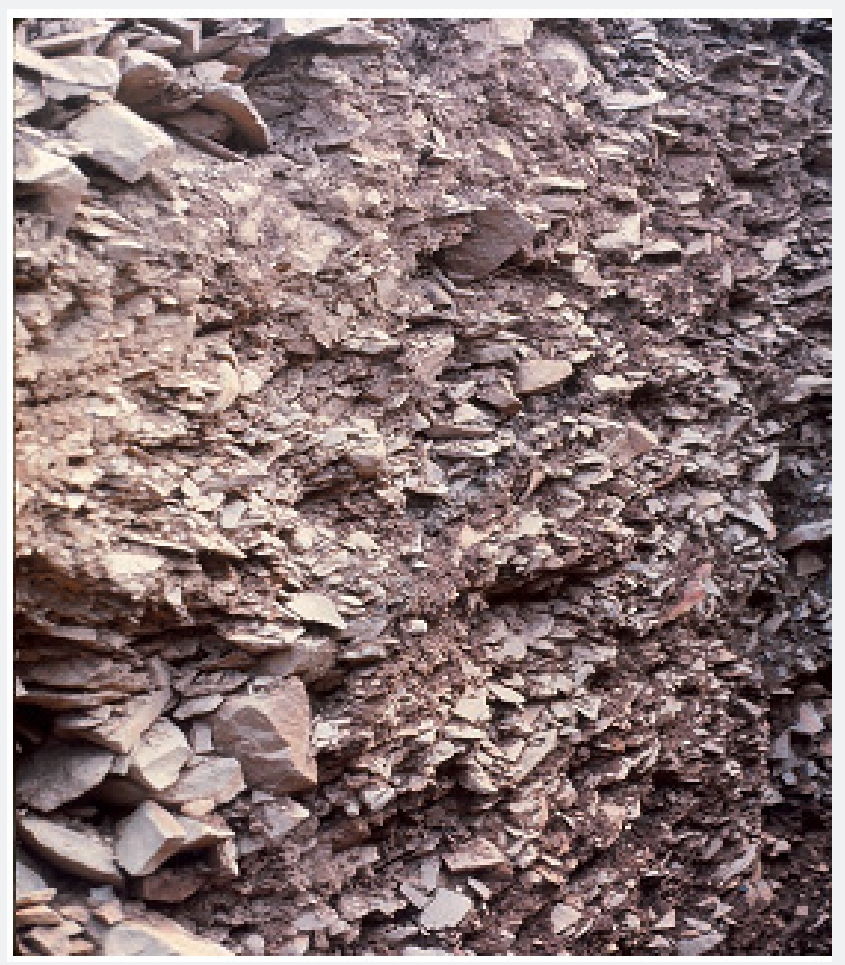

Figure 9: Detail of Test Trench I (UNN 1977-1978).

(Source: Allsworth-Jones, 2015) 


\section{Global Journal of Archaeology \& Anthropology}

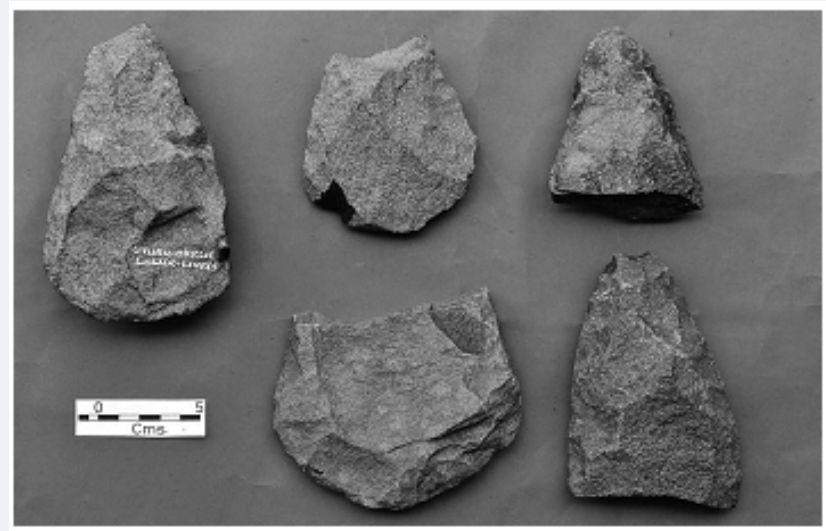

Figure 10: Artefacts from Uturu Lower Levels (Ibadan 1978).

(Source: Allsworth-Jones, 2015)

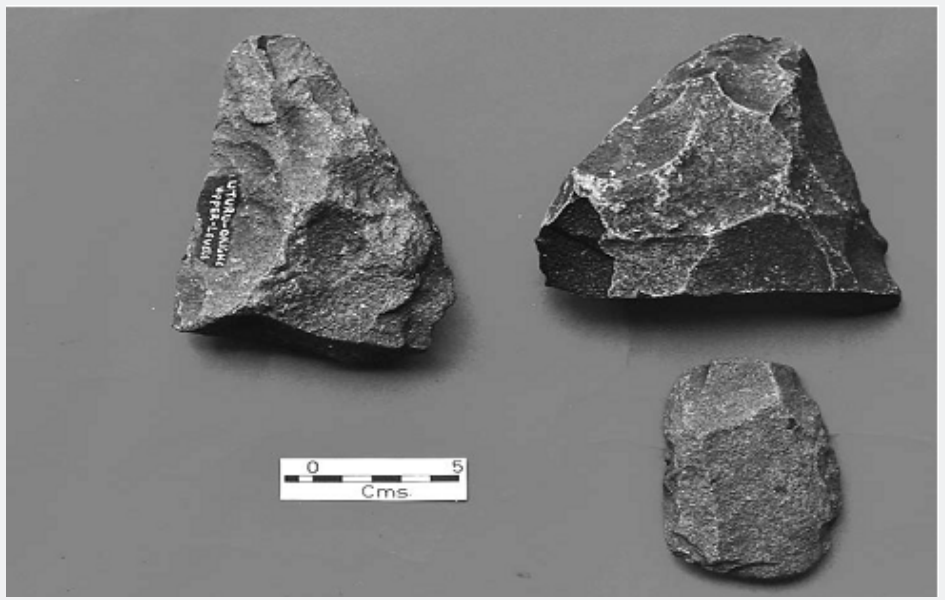

Figure 11: Artefacts from Uturu Upper Levels (Ibadan 1978).

(Source: Allsworth-Jones, 2015)

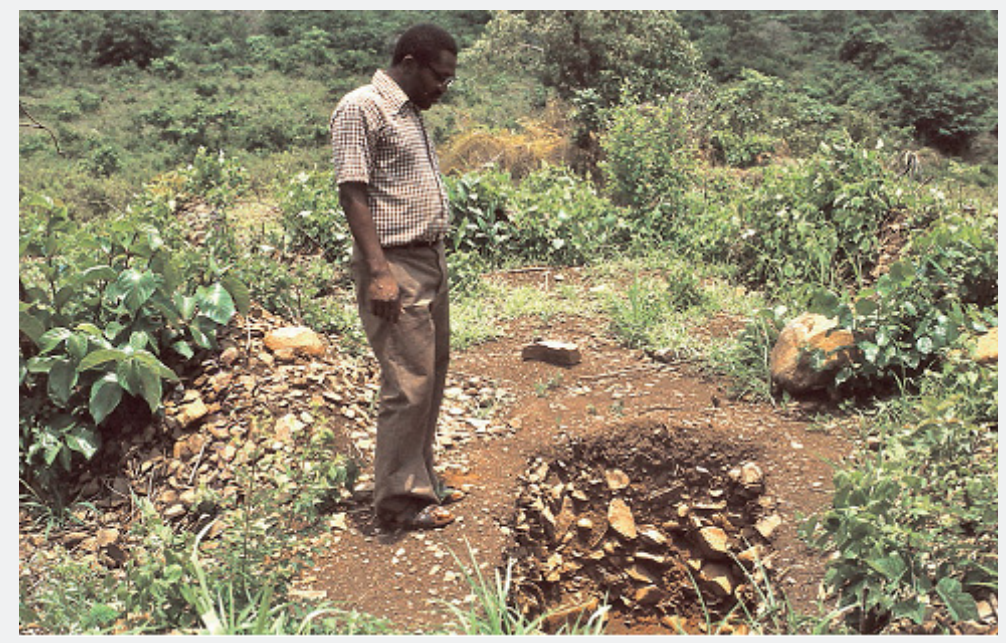

Figure 12: Test Pit '1' (UNN-UI 1981) with F.N. Anozie.

(Source: Allsworth-Jones, 2015) 


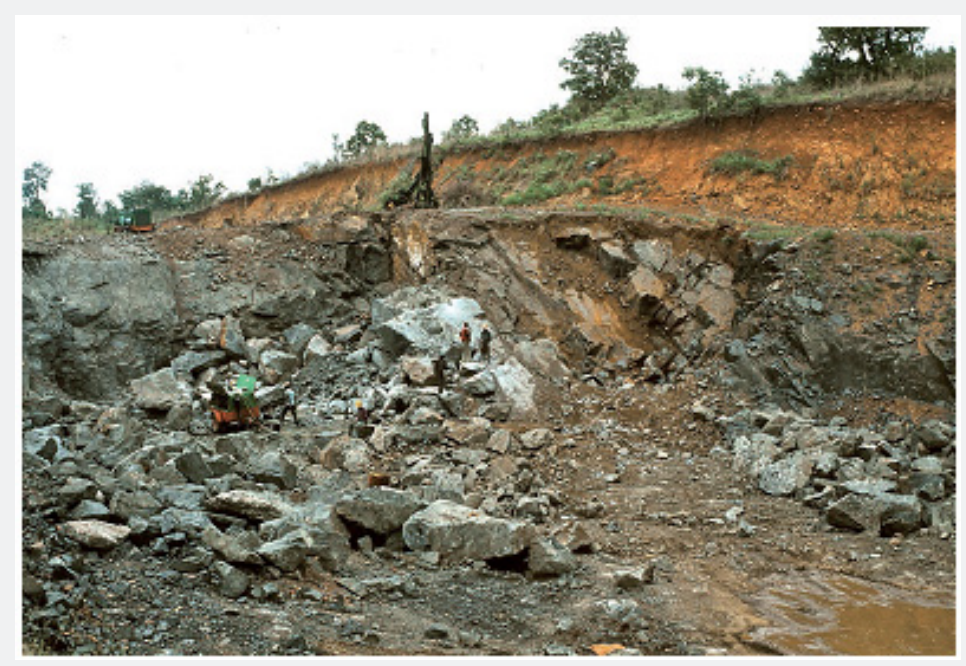

Figure 13: The construction company at work on another part of the site.

(Source: Allsworth-Jones, 2015)

\section{Further Archaeological Questions}

Evidences from the site at Ugwuelle in Uturu Area of Abia State and the arguments surrounding it motivated this research. This paper tends to reflect on Ugwuelle industrial site and its position further on the archeological map of Nigeria. Some cultural thoughts are necessary at this juncture towards preserving and promoting the archaeological understanding of the Ugwuelle industrial site. First reflationary point is on the nature of tools discovered at this site. It is quite understandable that stone tools discovered at the Ugwuelle industrial site are much like the famous Acheulean tools of the Middle Stone Age, a subsequent stone tool culture to the earliest Oldowan culture. These stone tools as can be seen in Figures 9-11 include hand axes, cleavers and picks of different sizes; most of which are in broken forms. Unfortunately, much of these tools are in fragments as a complete hand axe or cleaver like that of Mai Idontoro or Pingel in the Jos Plateau Acheulean cultures has not been found (Figures 14-17). This is evidenced from the reconnaissance conducted by the present researchers. This raises up a lot of questions like, (i) is Ugwuele truly Achulean? (ii) If Achulean, are the materials of primary or secondary workshop/redeposition? (iii) Were they preforms for Late Stone tools (ground/polished stone) axes as posited by Clark [15] and Allsworth-Jones [10] or not? From our experience through the archaeological reconnaissance conducted in the area, Ugwuele site is likely an Acheulean site as it contains all the lithic tools with which Acheulean sites are known all over the world [12, 21-25]. Surprisingly, 37 years after the first preliminary study (1977) was conducted on the site, lithic tools were still discovered through a focused ground reconnaissance as was conducted by the present authors in May, 2014. Finds of this recent reconnaissance were in harmony with those from the earlier preliminary investigations of the site as was published in the works of Anozie et al (1978), Anozie (1982), (1983), (1985), (1993), (2002), Andah and Derefaka (1983), Clark (1983), and Allsworth-Jones (1987 and 2015). It is an industrial site taking into consideration the abundance of raw materials in the form of dolerite stones and stone chips found within the vicinity. From our ground reconnaissance, we were of the opinion that the broken handaxes and the cleavers and the lack of complete ones could be that the makers selected the finished tools with which they hunt and dismember the animals killed and discarded the unfinished or broken ones only to re-visit the site when they run out or of tools. In addition, it is of primary workshop as there are no areas within the vicinity that such lithic raw material which breaks at a sharp edge could be found. Thus, natural environmental factors have a role to buttress this point. Down the slope of the hill is a stream which may have served as source of water to the workers/hunters. As for our last question, the Ugwuele site is not a direct preform or Late Stone Age in Africa. Though there is the appearance of Sangoan tools like picks, they occurred in small numbers when compared with the handaxes and the cleavers. No evidence of Late Stone Age tools (either of the lower or the upper) like the polished stone axes and the microliths of any form have so far been found in Ugwuele tool assemblage. It is our contention here that a further research outside the vicinity of Ugwuele in particular and Okigwe area in general may reveal where the finished products from Ugwuele were taken to. Furthermore, it is also our contention here that the tools were produced through chipping and flaking techniques and not the levallois technique as claimed by Anozie (1982). The technique of debiting carried out in the site can further add weight to this claim. Our reason for this lie on the fact that the raw material (dolerite stone and to some extent quartz materials used) are so hard to be worked on using bone as anvil and a hammer stone. Another call for thought is on the human remains. Hand axe culture is synonymous with 
Acheulean, Abbevillian and Chellean cultures (Balout, 1981). Evidence of human remains was recorded at these places in association with these stone tools. This was an indication of the manufacturers and/or users of these stone tools. Thorough studies at these sites made relevant inferences and premises in the existence and nature of humans at such sites. Such was not the case at Ugwuele owing to incomprehensive research. Stone tools discovered have not been associated with any human remain apart from the use of the cross-cultural dating and inferences by detailed and purposeful archeologists. This raises another reflationary point on the position of the Ugwuele industrial site in the world Archaeological Map. Moreover, another reflationary point is on the issue of systematic and comprehensive excavation.
Anozie (2002) asserted that the Ugwuele Industrial site was discovered in July 1977 and had first archaeological visit in October 1977, for a rescue excavation. Also during this rescue excavation it was noted that only two test pits of $2 \mathrm{~m}$ by $2 \mathrm{~m}$ was dug coupled with two trenches that were dug on $6 \mathrm{~m}$ by $2 \mathrm{~m}$ each. These excavations revealed multiple stone tools in industrial quantity which include handaxes, cleavers, picks and stone knives (Anozie, Chikwendu \& Umeji, 1981; Anozie, 2002). These rescue excavations shouldn't have been sufficient for such a magnificent and historical archaeological site. In some other similar sites in some other parts of the world, a much comprehensive excavation had been conducted with many other ones in progress so as to maintain detailed and more accurate archaeological inferences.

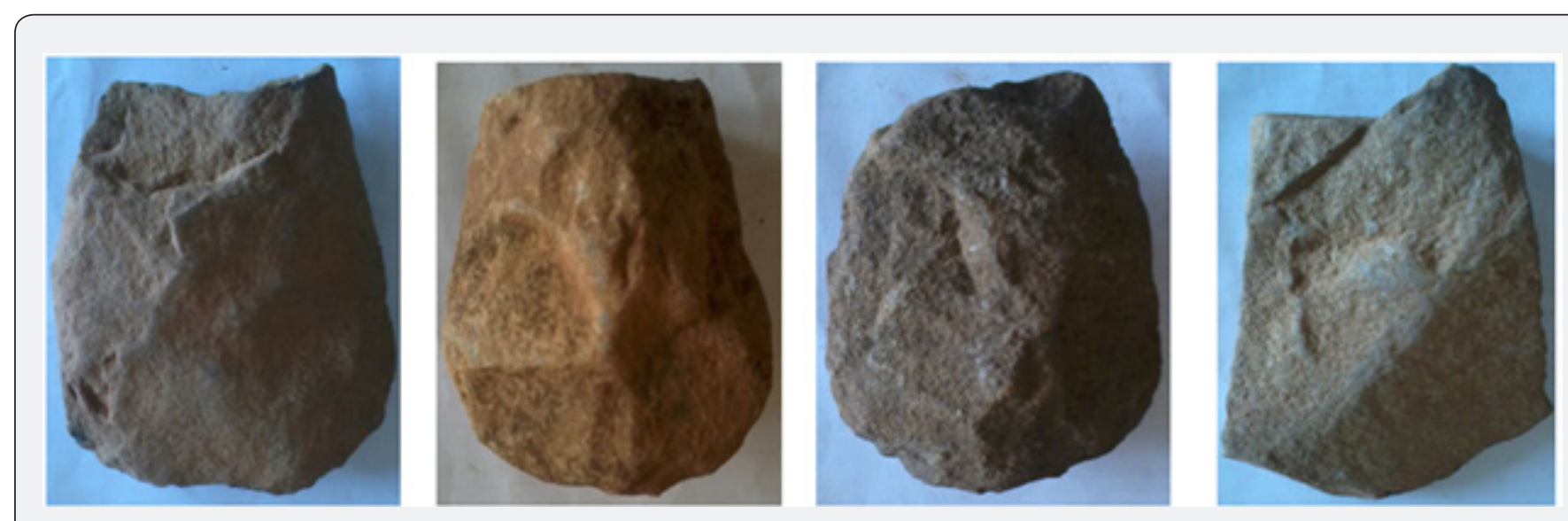

Figures 14, 15, 16 and 17: Samples of broken Hand axes found at Ugwuele Industrial Site on the 20th of May, 2014.
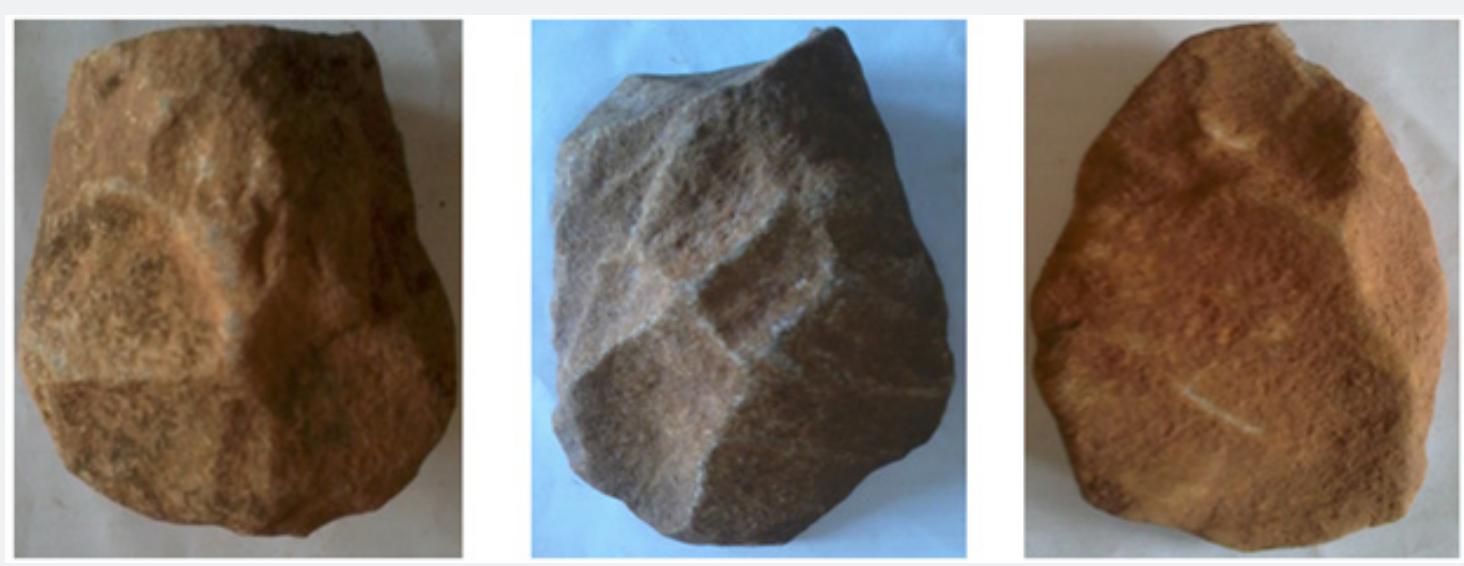

Figures 18, 19 \& 20: Some of the broken Acheulean handaxes from Ugwuelle Site as at 19th of May, 2014.

However, there are also issues on substantive dating for this site. According to (Braq \& Trump 1975, p.71) "time factor is obviously of paramount importance in archaeology and many methods of recording is employed". This is amongst the supporting factors of archaeological discoveries and inferences. The dating of a site aids in preserving the archaeological relevance of the site in a world of faster development and subsequent destructions of heritage resources. Although the Ugwuele site has not been dated, Clark (1974) had already noted before the discovery of the site, that similar culture in the other parts of Africa are put between 1.6 million and 95,000years BP (in Anozie 2002). Anozie who was amongst the first excavators of the Ugwuele site in 1977, when 
discussing on the age of the site noted as thus; "At present, the Ugwuele site has not been precisely dated but the culture is well known in Africa and its time range is undisputedly put at between 1.6million and 95,000 years BP; so the age of Ugwuele is within this range... judging from the tools, it seems that the site belongs to a phase which in other parts of Africa (Clark 1974) has been dated to about 500,000 years BP. We are trying to obtain a more definite date using the Carbon-14 and the potassium argon techniques of dating as sustainable dating materials were found at the site during the excavation, although we have some problems with these two techniques. We have also invited a geologist and a palynologist to see if the site could be dated by other means (Anozie 2002, p.18). Datable materials were also recovered by Anozie in his text trench II at the depth of 1.2 metres in form of extensive hearth and charcoal which according to him (Anozie 1982) were sent to Groningen for C14 dating(but inexplicably so far without result). Also excavations and dating at Iwo Eleru revealed that the site is about 11,000BC and likely earlier at Ugwuele (Shaw \& Daniels 1984). None of these have shown a substantive date for the Ugwuele industrial site. This factor has brought much segregation for this historic site in the world archaeological sequence and discuss. The nature of the site demands that proper dating will give more understanding and appreciation of historical and archaeological relevance of the site. Presently, most of the dates applied are from sites that are contiguous with Ugwuele. Finally, archaeological reflections are sacrosanct on the issue of surface collection in the site. During the recent ground reconnaissance on this industrial site at Ugwuele on the $19^{\text {th }}$ to $23^{\text {rd }}$ of May 2014, much of the stone tools (mostly in broken forms) (Figures 14 - 20) were still lying on the surface of the soil. Some of these stone tools were picked up and taken to the Archaeological museum of the Department of Archaeology and Tourism, University of Nigeria, Nsukka for further studies. The survival of these artifacts till date may be attributed to the fact that the site is not yet inhabited by people and the reserved areas have not been quarried. Presently, the community is using the area as farm site.

\section{Conclusion}

Allsworth-Jones [10] concluded his own view about the Ugwuelle site and its future in the following lines; I submit that the technological/typological profile of Ugwuelle and its stratigraphic context insofar as we know it fits far better with a Holocene workshop 'model' than it does with the kind of structure that we would expect in the Acheulean as detailed above. That the picture presents itself on the basis of the incomplete data we have at our disposal. What is needed now is a re-examination of all the evidence, coupled with an appraisal and possibly a fresh attempt to date the extant deposits at the site itself. Then we will be on a much surer footing [10] It is worthy to note that this study is a wakeup call to all relevant stakeholders in the field of archaeology. A detailed excavation is needed in the site which would help unravel some of the questions surrounding this site. It would also help in making a comprehensive study and inferences on the site like some other archaeological sites of similar cultures from other parts of the world. Series of test pits opened in the site by Anozie and his team during the initial discovery of the site, did not help in ascertaining the true nature of the site hence the current debate on its archaeological status. We propose in line with Okafor (1989) that an extensive and systematic excavation of six different pits of $10 \times 15 \mathrm{~m}$ in the site (which is currently under threat by the activities of SETRACO Querying Company) and a further reconnaissance survey of the site area. The depth of the six trenches should not just stop at the sterile layer but go beyond possible hiatus until no hiatus is further observed. Also, further Site Catchment Analysis (SCA) should equally be conducted on the landscape of the Uturu area of Abia State, Nigeria, to support findings from the excavation. This work should be executed by a conglomeration of seasoned archaeologists with members from Nigeria and some other parts of the world. Interestingly, some seasoned archaeologists from Nigeria, England and South Africa have already indicated interest in being part of this team. Departments of Archaeology in University of Nigeria and University of Ibadan in Nigeria should be fully involved since they are part of the history of the site. They are also expected to provide some of the equipment and human resources for the study. More importantly, a study of this kind, would need external funding for efficiency and unbiased report. This should be followed by series of systematic analysis, dating, interpretation and notable publications, which are expected to give answers to the critical questions raised in this paper. This is expected to dowse further debates on the archaeological relevance of the site since its discovery in 1977. Moreover, before the study, formal consultations and approvals should be sought after from the National Commissions for Museums and Monuments in Nigeria, coupled with the Commission's support towards the success of the study. Orientation programmes should be organized for the members of the host community on the proposed plan; how it will benefit them and their expected role. This will not only help in promoting and preserving Ugwuele Industrial site as a rich cultural heritage center in Nigeria and Africa in a wider scale [26-28] but also boost the tourism potential of Ugwuele community and Abia State In general. This would have settled various contentions on the site which made Okafor [12] to conclude his study on the site in the following lines. How can the cultural association be determined since enough geological data concerning the site are available, we should concentrate on the archaeology. What is needed is a full trench excavation, at least 10 by $15 \mathrm{~m}$ in size, in the decomposed bedrock area in order to expose the stratigraphic sequence. The area of the site that appears to be most promising is the undisturbed southern part of Reserve I, so the trench should be placed here. During the excavation, care should be taken to collect any available organic remains which could yield information on chronology, environment and ecological setting. The establishment of an adequate date for the site will settle all the arguments [12]. Finally, it is our contention here that from this research and evidences that turned up that Ugwuele archaeological site may be an industrial site and may 
have belonged to the Acheulean site as evidenced from the tools found in the area. The issue of accurate chronology of Ugwuele as we suggested awaits further archaeological researches through detailed archaeological excavations. It is earnestly recommended that this call for a total revisit to this site should be harkened to, through adequate collaborative efforts from relevant experts. As noted earlier, a research of this kind can only be funded by the National Commission for Museums and Monuments in Nigeria and other relevant funding agencies like UNESCO, with interest in culture and heritage preservation. The result of this research would answer most of the puzzling archaeological questions raised in this paper and also determine the value and position of the Ugwuele site in the world archaeological map.

\section{References}

1. Ki-Zerbo J (1981) General history of Africa, Educational Books Limited, London: Heinemann.

2. Bray W, Trump D (1975) The Penguin Dictionary of Archaeology. Penguin Books Limited, England.

3. Clark JD, (1970) The prehistory of Africa. Thames and Hudson, London.

4. Philipson DW (1985) African Archaeology. Cambridge University Press, Cambridge, United Kingdom.

5. Okpoko AI, Ekechukwu LC (2012) Terminal Acheulians and puddle Stone Age settlements. In Okpoko AI, Derefaka A (Eds.), Archaeology and Early History of Africa. Nsukka University of Nigeria Press.

6. Alagoa EJ, Derefaka AA (2014) The Origins and dispersal of Mankind from Africa. Commissioned paper presented at colloquium on Ijaw Genesis, Culture and Intergroup relations in the Niger Delta, Federal University Otuoke, Bayelsa state $8-11^{\text {th }}$ June, 2014.

7. Allsworth-Jones P (1987) The earliest human settlement in West Africa and the Sahara. West African Journal of Archaeology 17: 87-128.

8. Anozie FN (1982) Recent Archaeological Discoveries in Southeastern Nigeria. Historical Society of Nigeria (HSN) $27^{\text {th }}$ Annual Congress, Port Harcourt, $13^{\text {th }}-17^{\text {th }}$ April, 1-25.

9. Anozie FN (2002) Archaeology of Igboland: the early prehistory. In Ofomata GEK (Edn.), A Survey of Igbo nation Onitsha: Africana First Publisher Limited.

10. Allsworth-Jones P (2015) Ugwuele-Uturu: A lithic exploration site South-East Nigeria. Journal of African Archaeology 13(2): 215-232.

11. Anozie FN, Chikwendu V, Umeji A (1978) Discovery of a major prehistoric site at Ugwuele-Uturu, Okigwe. West African Journal of Archaeology, 8: 171-176.
12. Okafor EE (1989) Ugwuele stone age site: A search for solutions. Nyame Akuma 31: 30-31. A Newsletter of the Society of Africanist Archaeologists (SAFA).

13. Andah BW, Derefaka AA (1983) Field season at the Palaeolithic site of Ugwuele- Uturu, A preliminary report. Paper presented at the $9^{\text {th }}$ Congress of Pan-African Association for pre-history and related studies.

14. Marliac A (2006) Archeologie du Diamare an Cameroun Septenirional. Oxford: BAR International Series 1549, Oxford.

15. Clark JD (1983) The $9^{\text {th }}$ Pan-African Congress on Pre-history and Related Studies In: Nyame Akuma, Jos, $11^{\text {th }}-17^{\text {th }}$ Dec. 1983 , In, Nyame Akuma, 23: 1-4.

16. Anozie FN (1983) Preliminary analysis of the stone artifacts of Ugwuele Cyclostyled report. $9^{\text {th }}$ Congress of the Pan-African Association for Prehistory and Related Studies. Jos, pp. 1-6.

17. Anizie FN (1985) Archaeology of Igboland. Asele Institute. P.M.B 1001, Nimo, Anambra State, Nigeria.

18. Anozie FN (1993) Ugwuele earliest evidence for stone technology in Eastern Nigeria. In Andah BW, de Maret P \& Scoper R (eds.), The proceedings of the $9^{\text {th }}$ Congress of the Pan-African Association of Prehistory and Related Subjects. Jos, Rex Charles Publications: Ibadan. p. 176.

19. Anozie FN, Chikwendu V, Umeji A (1981) The discovery of a major prehistoric site at Uturu. West African Journal of Archaeology (WAJA).

20. Clark D (1974) Africa in Prehistory: Peripheral or Paramount. Man, 10,175-198.

21. Balout L (1981) Prehistory of North Africa. In Ki-Zerbo J (edn.), UNESCO General History of Africa I. London: Heinemann, United states.

22. Clark JD (1981) Prehistory of Southern Africa. In Ki-Zerbo J (edn.), UNESCO General History of Africa I London: Heinemann. 487-529.

23. Shaw T (1981) The prehistory of West Africa In Ki-Zerbo J (edn.), UNESCO General History of Africa I. London: Heinemann. 611-633.

24. Soper RC (1965) The stone age in Northern Nigeria. Journal of the Historical Society of Nigeria 3: 175-194.

25. Sutton JEG (1981) The prehistory of East Africa. In Ki-Zerbo J (edn.), UNESCO General History of Africa I. London: Heinemann.

26. Itanyi EI, Okonkwo EE, (2010) Archaeological Investigations in Okigwe Area. Nsukka Journal of the Humanities (NJH) No. 18: 181-193.

27. Anozie FN, Chikwendu V, Umeji A (1981) The discovery of a major prehistoric site at Uturu. West African Journal of Archaeology Vol 9.

28. Shaw T, Daniels SGH (1984) Excavation at Iwo-Eleru, Ondo State Nigeria. West African Journal of Archaeology Vol 14. 
This work is licensed under Creative Commons Attribution 4.0 License DOI: 10.19080/GJAA.2021.11.555821

\section{Your next submission with Juniper Publishers} will reach you the below assets

- Quality Editorial service

- Swift Peer Review

- Reprints availability

- E-prints Service

- Manuscript Podcast for convenient understanding

- Global attainment for your research

- Manuscript accessibility in different formats ( Pdf, E-pub, Full Text, Audio)

- Unceasing customer service

Track the below URL for one-step submission

https://juniperpublishers.com/online-submission.php 